\title{
Accounting for Parent Money in a Public School
}

\author{
Andrea Voyer ${ }^{\bullet}$ \\ Associate Professor \\ Department of Sociology \\ Stockholm University \\ andrea.voyer@sociology.su.se
}

August 28, 2019

Word Count: 14,661

- This research was supported by the Russell Sage Foundation under Grant Number G-6849. The author would like thank Gabriel Abend, Vanessa Barker, Stina Bergman-Blix, Jessica Calarco, Elsa Davidson, Sean Drake, Maura Finkelstein, Adam Gamoran, Anna Lund, Elayne Oliphant, Annabella Pitkin, Danilyn Rutherford, Iddo Tavory, Elizabeth Thomson, the RSF 2017 Visiting Scholars, the Stockholm University Sociology Department Seminar, the NYU Ethnography Workshop, and the Qualitative Data Repository Annotation for Transparent Inquiry Workshop for helpful comments on earlier drafts of this manuscript. 


\begin{abstract}
Since the 1990s, parent funding of American public schools has increased. Past research offers three explanations of this phenomenon: 1. the economic explanation maintaining that parents contribute in order to supplement lagging public investments in education; 2 . the opportunity hoarding explanation arguing parents contribute to secure educational advantages for their children; and 3. the civic engagement and social capital explanation that sees parent fundraising as an element of parents' democratic participation in schools. This article considers the efficacy of these explanations in the case of parent fundraising in a Manhattan elementary school I call PSX. Applied to data collected through ethnographic research among PSX parents, the existing explanations provide an incomplete understanding of parent fundraising because they focus on the intentions and motivations of parents. A normative-institutional perspective provides additional explanatory leverage. Educational policy and normative expectations link parental fundraising and school quality. The money supplied by parents is an easy-to-read measure of a good school, and, by association, good parents. Parents give and give more because that is what they are asked to do.
\end{abstract}




\section{Introduction}

Since the 1990s, parent fiscal contributions to public schools have risen dramatically. The rise and role of parent money in public schools is of interest to scholars seeking to understand inequality within and between schools. Past research typically explains the rise and role of parent money in public school with some combination of three explanations: 1. the economic explanation maintaining that parents contribute in order to supplement lagging public investments in education; 2. the opportunity hoarding explanation arguing parents contribute to secure educational advantages for their children; and 3. the civic engagement and social capital explanation that sees parent fundraising as an element of parents' democratic participation in schools.

The aim of this article is to evaluate these explanations by applying them to the case of parent fundraising in a New York City public elementary school I call PSX. ${ }^{1}$ Through ethnographic research examining parent financial contributions to the school, interviews with parents about their perspectives and behaviors when it comes to supporting their children's school, and complementary background research linking those behaviors and perspectives to education policy, I find that existing explanations do not fully account for parent money in public schools because their focus is on the intentions and motivations of parents. While the desire to supplement public money, opportunity hoarding, and a commitment to civic engagement all play a role in parent fundraising at PSX, parent giving to the school is constructed within a web of expectations and institutional arrangements that lead to parent fundraising. Put simply, there are

\footnotetext{
${ }^{1}$ All individuals and organizations have been given pseudonyms. Other identifying details were obfuscated by the introduction of less precise dates, numbers, locations, etc.
} 
widely shared norms around parental involvement and, in giving money to the school, parents are doing what they are asked and expected to do.

Mounting evidence does confirm fears that parental involvement in education, including monetary contributions, is a source of educational inequality (Brown et al. 2017). In order to be effective, responses to this issue must address the causes of the rise of parent funding of public schools. Rising parental support for schools coincides with increased demands for parental involvement, which were formalized in national educational policy in the 1990s. As established by policy, a good school is a school with engaged parents. PTA fundraising totals and the menu of programs funded by the parents are easy to read metrics of parental engagement, which is taken as a measure of school and parent quality. As long as schools are evaluated on the basis of parental involvement and parents are not prohibited from raising funds for the school, we can expect continued growth of parent fundraising, and concomitant impacts on inequality.

\section{Parent Fundraising in the Literature}

Although American parents have provided supplemental funding to public schools, research has documented a dramatic increase since 1995 in the money flowing into schools through schoolsupporting not-for-profit organizations (Brunner and Imazeki 2004; Christensen et al. 2016, De Leon et al. 2010, Haar 2002, Murray et al. n.d. Nelson and Gazley 2014). Parents are a crucial source of these funds, and they also supply necessary economic and human resources for the formation and operation of school-supporting organizations. Of such organizations, which include booster clubs, educational foundations, alumni associations, and parent-teacher associations, PTAs are the most common - making up more than $70 \%$ of school supporting nonprofit organizations in 2007 and 2010 (de Leon et al. 2010, Nelson and Gazley 2014). The 
number of PTAs in the United States tripled between 1995 and 2010 (Nelson and Gazley 2014).

PTA revenues have also risen by 3.9 times over the same period, topping $\$ 400$ million dollars in 2010 (Nelson and Gazley 2014). This amount may seem a mere "drop in the bucket" when compared to the combined $\$ 593.7$ billion states, municipalities, and the federal government spent on public elementary and secondary education in the United States in the same year (Brunner and Sonstelie 2003; Dixon 2012). However, PTA fundraising is concentrated in schools and districts with higher income families (Addonizio 2000, Brown et al. 2017, Brunner and Imazeki 2004). In 2010, only $20 \%$ of school districts had at least one revenue-generating PTA (Nelson and Gazley 2014). There is also state-based variation in the relationship between PTA revenues and urbanicity, school size, and school diversity. ${ }^{2}$ Due to the uneven distribution of PTAs and revenue-generating PTAs in particular, and because PTAs and other school-supporting organizations are independent of the schools they support, parent volunteer hours are not reported and their monetary contributions are not typically included in the schools' records of educational expenditures (Haar 2002). As a result, measures of investments in education likely underestimate this source of educational inequality (Addonizio 2000; Brown et al. 2017).

Past research has offered various explanations for the rise of this phenomenon, but the most prevalent are the economic, opportunity hoarding, and civic engagement explanations.

\section{The Economic Explanation}

\footnotetext{
2 Brunner and Imazeki (2004) find a positive relationship between PTA fundraising and diversity and urbanicity in California and a negative relationship between parent fundraising and school and district size. Meanwhile, Murray et al (2019) find that North Carolina schools with more students are more likely to have high revenue PTAs, but the percentage of minority students within the school is negatively related to PTA revenues.
} 
The economic explanation maintains that increases in monetary contributions from parents coincide with declining or stagnating public school revenues and schools' decreased flexibility in spending (Addonizio 2000, Brunner and Imazeki 2004, Brunner and Sonstelie 2003). Motivated to address the gap between the needs of the school and the public funds available, families work collectively to support the school. Collective activity, such as fundraising through the PTA, is important because it increases participation, allowing more parents to share the financial burden of supporting the school (Brunner and Sonstelie 2003). This explanation for increased parent funding of public schools has some problems. First, research has shown that the rise in parent contributions is not predicted by changes in federal and district-based funding (Nelson and Gazley 2004). In fact, better-funded districts and those with more federal funding also receive more parental contributions while, in districts where there is decreased public funding, parental contributions have not generally offset those decreases (Nelson and Gazley 2004). Second, parent giving to schools is inefficient as parents often spend more by giving to the school than they would by individually procuring the desired services or by funding schools collectively through taxation (Brunner and Imazeki 2004, Brunner and Sonstelie 2003). Third, parents contribute to schools at higher rates than predicted by economic collective action models based on this explanation (Brunner and Sonstelie 2003).

\section{Opportunity Hoarding}

It's the advantages provided by parents that loom large in the opportunity hoarding explanation (Tilly 1998, Reeves 2017). From this perspective, better-off parents "work the system on behalf of their kids" (Lewis and Diamond 2015, p. 153). Motivated to improve their children's chances of educational success, parents engage in a variety of activities - including seeking spots in accelerated or special programs (Lewis and Diamond 2015, Reeves 2017), instructing their 
children in tactics for "negotiated advantage" in the classroom (Calarco 2018, Lareau 2000), and participating in the school PTA in order to directly help their children (Lewis and Diamond 2015, Posey-Maddox 2014). Not just a reflection of extant social inequality, opportunity hoarding conveys its own advantages above and beyond other advantages that accrue to children of parents who have more economic, social, and cultural capital. It is the result of the conscious use of resources to give a child an edge over other students who are, on the basis of the hoarding behavior, relatively disadvantaged.

Parent money in public schools can be seen as opportunity hoarding because such funds provide school-based academic advantages over schools without such parent investments (Murray et al. 2019), because parents who donate to the school are in a better position to exert influence within the school in order to secure advantages such as placing their children with highly regarded teachers or disregarding teacher's placement recommendations and opting for accelerated and advanced courses (Lewis and Diamond 2015), and because the children of parents who support the school may receive preferential treatment in the classroom (Calarco 2018, Posey-Maddox 2014). There have been few evaluations of the accuracy of the opportunity hoarding explanation. Hanselman and Fiel (2017) examined opportunity hoarding as a potential mechanism connecting school segregation and educational inequality and find that opportunity hoarding provided little additional explanatory leverage over the idea that inequality through school segregation arises as students are sorted on the basis of prior academic achievement.

\section{Civic Engagement and Social Capital}

The civic engagement and social capital explanation maintains that parent money in public schools is an expression of community orientation and a form of civic engagement channeled 
through PTAs, which are important school-based civic associations (Christensen et al. 2016, Crawford and Levitt 1999, Murray et al. 2019, Putnam 2000). PTAs provide funds and other necessary resources, and involved parents represent and advocate for the school through their visibility and participation in broader social and governmental institutions such as school boards and city councils. Parents take an active role in school governance, and they build social capital through opportunities for socialization, civic training, and the development of helpful parent networks (Christensen et al. 2016, Putnam 2000, Small 2010). In direct contradiction to the assumptions of opportunity hoarding, the civic engagement explanation maintains that involved parents and the funds they raise are often opportunity creators producing social capital with a salubrious effect that extends beyond parents and the school to American democracy and civil society in general (Christensen et al. 2016, Crawford and Levitt 1999, Putnam 2000).

The civic engagement and social capital explanation suffers from some significant problems. First, this perspective does not differentiate between types of parental involvement - treating assisting with homework, helping in the classroom, and donating significant sums of money as civic activities. Second, the civic engagement explanation generally assumes that inequality is not endemic to involvement, but is merely something that arises on account of inadequate rules and management of parents, or the substitution of paid membership for in-person civic participation that may include financial contributions (Skocpol 2013). Yet, American political and civic involvement has long amplified the voices and supported the interests of wealthier and better educated Americans (Verba, Schlozman and Brady 1995). Third, this explanation does not take account of the costs of participation - what other things parents might be doing with their time and money if they were not supporting their children's schools (Griffith and Smith 2005). 
The aim of this article is to examine the efficacy of these explanations in accounting for parent fundraising in a New York City public elementary school.

\section{Data and Methods}

Data were collected through a 28-month ethnographic study of PSX parents as part of a study of broader study of inequality in civic organizations. Parental involvement in and support of public schools are recognized as paradigmatic examples of democratic civic-mindedness, and as a site for the reproduction of social inequality as well (Murray et. Al 2019, Putnam 2000). I first describe PSX and the rationale for studying the school. I then describe the methods of data collection and analysis.

PSX

PSX sits in the midst of public housing projects in a Manhattan neighborhood that has undergone rapid gentrification. In 2016, about $25 \%$ of people in the school's zip code lived below the poverty line, meanwhile more than $20 \%$ of people lived in households with an annual income greater than $\$ 200,000$, putting them in the top $2 \%$ of households in the United States, and the top 5\% of households even in well-off New York City (US Census Bureau 2017). These socioeconomic extremes are reflected in the school. PSX experienced declining enrolments as the neighborhood gentrified. A "gifted and talented" program (G\&T), an accelerated track with admission by examination for students from the school district, was developed to increase demand for seats. The school continued serving "general education" (GenEd) students who lived within the immediate neighborhood. 
Enrolments increased after the introduction of G\&T. White and Asian children began attending what had been a primarily Black and Latinx school. In 2006, before the introduction of G\&T, between nearly $90 \%$ of students at PSX came from families receiving public assistance, in 2016 approximately $40 \%$ of students came from families receiving public assistance. In 2006, about $50 \%$ of students were Hispanic, about $30 \%$ were African American, about $15 \%$ were Asian, and less than $5 \%$ were white. In 2016, $30 \%$ of students were Hispanic, about 25\% Asian, $25 \%$ white, and $15 \%$ African American. ${ }^{3}$ In 2016, the approximately 600-student body was about $30 \%$ Latino, 25\% Asian, 25\% white, and 15\% black. Around half of students qualify for free or reduced-priced lunch.

PSX was selected as a research site because of its racially and economically mixed population, which tends to be segregated in the school's two tracks, and its active PTA. Despite the segregation of educational tracks at PSX, there is only one PTA. New York City public schools are required to have a PTA, and parents are automatically members. PTAs are charged with advocating for students and their families, facilitating communication between parents and the school, organizing activities, and supporting the school through fundraising, volunteerism, and educational programming for parents. ${ }^{4}$ In 2016 the PSX PTA budget was approximately $\$ 450,000 .^{5}$ This budget is in line with the norms among high-revenue parent organizations in

\footnotetext{
${ }^{3}$ Data on New York City Schools is available through the City of New York https://tools.nycenet.edu/dashboard/, the State of New York https://data.nysed.gov/, and the National Center for Education Statistics https://nces.ed.gov/ccd/schoolsearch/

${ }^{4}$ For more information see New York City Schools guidelines for Parent and Parent Teacher Associations https://www.schools.nyc.gov/school-life/get-involved/parent-associations

5 Per pupil expenditures in NYC public schools 2016-2017, $\$ 20,724$. But when you pull out the children who receive special education services, per pupil expenditures are $\$ 15,736$. In the same year PSX per student expenditures were about $\$ 18,000$. This means that the PTA funds, approximately $\$ 750$ per child is a $4 \%$ increase in per pupil expenditures. However, that base number includes physical plant, busing, meals, and other fixed costs. Considering expenditures on instruction only, NYC per pupil expenditures for typical students are $\$ 9034$. This
} 
New York City, and the United States at large (Brown et al. 2017). The PSX PTA raises funds through classic PTA fundraisers such as raffles, bake sales, coin drives, book fairs, and box top collection (see Putnam 2000). The organization's largest sources of income are a $\$ 150$-perperson black-tie gala and auction, a direct appeal fundraising campaign that targets parents, aggressive pursuit of corporate matches ${ }^{6}$, and a walk-a-thon. Many of these activities are also common in other high-revenue PTAs in New York City and elsewhere (Brown et al. 2017). As described below, the PSX PTA is dominated primarily by G\&T parents.

\section{Team Ethnography}

Once approved by the Institutional Review Board of the New York City Department of Education, I approached the PSX principal, who granted permission for the research. Due to the focus on PTA fundraising, I also obtained the consent of the Executive Board (EB) of the PTA. Opt-out consent forms were then sent home to all parents. A handful of parents declined to participate.

The research was conducted through team ethnography. The team consisted of myself and a research assistant. Given its strength as a tool for detailed observation of social processes, cultural interpretations, routine behaviors, and the interaction between the local and larger systems of meaning and practice, ethnography is an appropriate method for the study of the role of parent money in public schools (Marcus 1995). Some fieldwork was conducted independently

means that the PSX PTA money is an $8 \%$ increase over the average expenditures on instruction. Spending on student activities is about $\$ 424$ per for typical students in New York City. Since most PSX PTA money goes to enrichment, that would more than more than doubles the average spending on enrichment. New York City expenditures data are available here: https://infohub.nyced.org/reports-and-policies/financial-reports/financialdata-and-reports/new-york-state-school-funding-transparency-forms

${ }^{6}$ When a company makes a charitable contribution to organizations that their employees support independently. 
and some fieldwork was tandem. We wrote detailed fieldnotes recording observations and interpretations of observations and encounters in the field. As expected in team ethnography, differences in interpretation of observations were common, provided valuable insight, and acted as an element of quality control establishing the limits of the researchers' interpretations (Erickson \& Stull 1997). Frequently the other team member supplied observations and interpretations that corroborated and extended what one person is able to see and understand. In the present article, team ethnography encompassed data collection only. Unless otherwise stated, extended ethnographic descriptions are drawn from my own fieldnotes with potential corroborating information from the assistant's tandem fieldnotes.

Between Fall 2015 and Spring 2018, we logged between 4 and 12 hours of weekly fieldwork when school was in session. We attended PTA meetings, volunteered at events, participated in organizing committees, and socialized with parents before and after school. We identified ourselves as researchers, and openly took notes and recorded in meetings. After the first year of fieldwork, we supplemented ongoing observation with 24 interviews of a purposive heterogeneous sample of parents. The interview focused on parental involvement, including parents' financial contributions to the school. We used our familiarity with PSX to identify some interview subjects who were quite involved at school, others who were not at all involved, and parents in between; parents of both gifted and talented and general education students; mothers and fathers; white, black, Latinx, and Asian parents; wealthy parents and parents on welfare. Interviews were conducted by both researchers, most often together. The data resulting from these research activities includes hundreds of pages of fieldnotes and field documentation such as handouts from PTA meetings, advertising for parent activities, and email correspondence sent 
from the PTA to all parents. Data also include recordings and transcripts from interviews and PTA meetings. NVIVO qualitative data analysis software was used to organize the data, which were first index-coded, then coded for emergent topics that arose during the analysis, and then thematically coded for additional topics important for the present article (Deterding and Waters 2018).

Two analytical approaches guided analysis of the data - an interpretive focus on the meaning parents attach to fundraising and an institutional ethnographic focus on the linkages between parents' interpretations and social organization. Interpretivists seek to uncover the landscape of meaning of action - the sense-systems motivating people to action and forming the ways in which they act on their motivations (Reed 2011). However, intrepretivism alone is insufficient for making sense of parent PTA participation and fundraising because there are also institutional contexts of parental involvement which may extend beyond the awareness of parents. Institutional ethnography builds from people's everyday experiences to the institutional arrangements shaping those experiences (DeVault 2006, Griffith and Smith 2005, Rankin 2017, Smith 2005). More specifically, institutional ethnography focuses on similarities in the behaviour and beliefs of parents in different circumstances and traces their connection to institutional relationships and hierarchies. By examining the convergence of different people's efforts and understandings, institutional ethnographers uncover 'ruling relations' - extra-local forces consisting of interests, ideologies, discourses and socially established practices - that maintain a particular social order (Smith 2005, DeVault 2006). From this perspective, parents' interests, concerns, and actions when it comes to making financial contributions to PSX offers a view of a broader system - the organization of parenting, schooling, and inequality in the United States. 


\section{Reflexivity and Limitations}

My past experience moving to New York and joining the PTA of my children's public school

(one year as secretary and another as chair of community-building) prompted this research. I did not hide that I was a parent with prior PTA experience. Sometimes my familiarity with New York City public schools and their policies facilitated a connection with parents. At other times, my status as a white woman (and possibly also a parent) with an upper-middle-class manner who was known to attend PTA meetings and other school events made it more challenging to connect to parents who distrusted the primarily white and Asian parents monopolizing PTA leadership positions. My research assistant, a recent college graduate who is a Latinx woman and native New Yorker, made initial contact with some parents I had not met (and vice versa). She also struggled to access distrustful parents. The extended timeline, consistent fieldwork for two and a half school-years, was the key to access. By the end of the research, we were known and trusted by many parents. Only rarely were we unsuccessful in our attempts to connect.

There are limitations in ethnographic work. As the data concerns only one case, we make no claims to the broader generalizability of our findings. Data collected through consistent presence in the field and the establishment of personal relationships is also not reproducible. However, “empirically following the thread of cultural process" (Marcus 1995, 96), from PSX to the broader context of parent involvement in public education, is an "extended place method" (Duneier 2001) linking the specifics of PSX with a broadly relevant institutional context. When possible, I describe what is unique and what is not unique about parent fundraising at PSX. Therefore, this study can be used to assess existing explanations of the rise of parent money in public schools, and to develop alternative explanations that may apply to other contexts. 


\section{Analysis}

In evaluating existing explanations of parent money in public schools against the case of parent money at PSX, I first consider the economic explanation, followed by opportunity hoarding, and then civic engagement and social capital. While each explanation offers some traction, they are insufficient to account for the nature of parent financial support of PSX. To fill the gap, I offer a normative-institutional account of parent money in public schools.

\section{Economic}

According to the economic explanation, increased monetary contributions from parents coincide with declining or stagnating public school revenues and decreased flexibility in spending (Addonizio 2000, Brunner and Imazeki 2004, Brunner and Sonstelie 2003). Consistent with this explanation, parent fundraising efforts at PSX arose as a response to decreased public funding. However, parent fundraising more than replaced the lost funds.

\section{Parents Respond to Declining Revenues}

With the introduction of the gifted and talented program, half of the seats in PSX went to children who scored in the top few percentiles on the gifted and talented examination. Children taking and scoring well on the exam were more likely to be Asian and White than black or Latino, to be residents of wealthier neighborhoods, and have access to paid exam preparation (Gootman and Gebeloff 2008). The influx of G\&T students shifted the school's demographics, as described above. As a result, a few years before this research, the school lost $\$ 250,000$ in funding when the percentage of documented low-income students dropped below Manhattan's $60 \%{ }^{7}$ eligibility threshold for federal Title I funds for low-income schools. According to multiple

${ }^{7}$ For more information on title I, see the Archived Tip Sheet https://cecdistrictone.files.wordpress.com/2016/03/title-1-tip-sheet.pdf 
parents who were in the school at that time, the principal learned after the school year was underway that PSX would lose funding for that year. She addressed the assembled parents at a PTA meeting and announced that, unless parents raised additional money for the school, she would discontinue the music program and curtail spending on supplies. At that time, the PSX PTA did not prioritize fundraising. The PTA had not raised more than $\$ 12,000$ in any given year for which records were available. Galvanized by the loss of funds, a group of PTA parents held a fundraiser. They raised about $\$ 80,000$ and saved the music program.

At first blush, the mobilization of school parents seems consistent with the economic explanation. However, while the loss of Title I was the shock that mobilized PSX parents, in truth the resulting change in fundraising activity brought the PSX PTA in line with other high revenue PTAs (Brown et al. 2017). What is noteworthy, then, is how unremarkable it is that, when faced with a budget shortfall, the principal turned to the parents, who accepted the responsibility and used pre-existing resources, strategies, and organizational partners to develop a fundraising organization. The mobilization of the PSX PTA occurred under particular circumstances, but there was nothing novel in the idea that parents would provide financial support to their public school.

In subsequent years, fundraising continued and accelerated. Just a few years later, in 2016-2017, the revenue of the PSX PTA was almost twice the amount of the lost Title I funds. The money was spent on community activities such as school talent shows, holiday performances, community dinners, and a neighborhood fair. The PTA provided an assistant teacher for each classroom, offered supplementary allowances for the teachers and principal, secured preparatory 
courses for required standardized tests, and purchased music and theater classes, robotics classes, and gardening opportunities, among other things (See Table 1). Even with all of these programs, the PTA's ability to raise money eventually outpaced their desire to spend it.

\section{Fundraising Outpaces Need}

In May 2016, the PSX PTA convened the monthly meeting. When it began about 35 parents occupied a portion of the old floor-mounted, unpadded folding wood laminate seats in the auditorium - a small crowd dwarfed by the 350-person capacity of the space. Attendance was likely low because it was a rainy morning. Between 60 and 80 parents typically attended the PSX monthly PTA meeting and approximately $20 \%$ of children have a parent who attends PTA meetings regularly. ${ }^{8}$ The meeting was running long. It began at 8:45 a.m. Parents began trickling out of the auditorium just before 9:20, the time when parents visit the classroom and to "learn with your child." At 9:30 the principal concluded her remarks and still others departed. As the meeting wound down, Maggie, PTA president and a white well-off mother with teaching experience who worked in fundraising, stood before about a dozen assembled parents. She used the matter-of-fact tone of someone eager to draw things to a close. "We are under-budget and we have done well with our fundraising efforts this year. Several teachers will be attending professional development seminars this summer. It is about $\$ 800$ a week. We would like for the PTA to help subsidize that. We want to support our teachers, and to do that we are proposing that we allocate $\$ 4000$ to help underwrite the cost of their professional development. I would need a motion to approve it." The motion was granted and approved immediately. Just as quickly as you can say, "All in favor. Any abstaining. Any opposing. Thank you."

\footnotetext{
${ }^{8}$ Analysis based on observation of meetings and attendance lists.
} 
"And one other quick resolution we would like to propose. Since our playground is fully funded ${ }^{9}$ we have the $\$ 15,000$ we raised through our coin drive and other initiatives... I spoke with the principal and she says the funds are really not needed. So rather than leaving the funds sitting, part of the job of Green \& Mean NYC [an organization that promotes urban gardening] is to make school spaces greener and more useful." Maggie described the conditions in the school's front yard - a sorry-looking 10x5 meter patch of grass with rotting benches and scraggly plants behind a rusting chain-link fence. "Green \& Mean NYC has offered to come in and make it into more of learning space and a place where kids can get together ... So we propose to move the $\$ 15,000$ to sort of fund that, and to making new benches, a living wall with plants and things growing out of it, just to make it into a more usable space for the kids." Maggie solicited a motion to approve, which was granted, seconded, and approved unanimously and without issue by the parents still present at the bitter end of the May 2016 PSX PTA General Meeting. The allocation of $\$ 19,000$ in PTA funds took less than three minutes.

PSX parents initially mobilized to replace lost public money, but fundraising quickly extended to support a wide-ranging budget. Furthermore, the PTA raised money a year in advance, which means that in the few years since the loss of Title I, the organization not only funded its annual activities, it also saved enough money to cover the budget for the next year. As a result, with a budget windfall and all the needs of the school apparently met, and with even the principal

\footnotetext{
${ }^{9}$ Following a successful grant application written by the parents and submitted on behalf of the school, a nonprofit organization was working with the school to plan the playground, and would assume the costs of construction.
} 
feeling that she had no use for more money, the PTA leadership allocated funds to a vaguely articulated plan for the front garden, something not previously discussed as an action item.

The choice to spend surplus funds may not run afoul of the economic explanation, but the underlying irrationality of parent fundraising is apparent in another agenda item discussed in the same meeting. Earlier that morning parents were reminded of the upcoming Mother's Day bake sale, a fundraiser that required parents to send in sweets, to sign-up for a shift selling the treats, and to send money with their children, who were the intended customers. A PSX bake sale typically yielded between $\$ 800$ and $\$ 1200$ dollars. Given the budget surplus, why did the PTA persist with fundraising?

\section{Opportunity Hoarding}

The opportunity hoarding explanation offers insight by shifting parent's motivation from making up gaps in funding to pursuing educational opportunity. There is certainly opportunity hoarding at PSX. Many parents described their financial support of the PTA and the school as motivated by a desire to confer advantages on their own children. However, opportunity hoarding as an explanation of parent money at PSX also has limitations as the pursuit of advantage was evident among both parents who were well-off and those who were struggling. In addition, at PSX there was also collectivism that is inconsistent with opportunity hoarding.

\section{Earning a Spot}

The G\&T program at PSX tends to draw families that use their resources to secure educational advantages. Just accessing special programs like gifted and talented education is often considered opportunity hoarding in the literature (e.g. Sattin-Bajaj and Roda 2018). Saaida is a parent whose giving to the school could be interpreted as opportunity hoarding. A doctor, and 
naturalized American born in Southeast Asia, Saaida is in her late 30s. She is a firm believer in public schools and she and her husband intentionally bought a condo in a neighborhood with great schools. Then they heard about G\&T education, so they bring their son across town to attend PSX because, she says, "we just believe in it... I believe in pushing kids... If he earns a spot in G\&T, he should be with like-minded peers." According to Saaida, getting into PSX was "partly luck, and it's partly just going through the process" with both paid and at-home exam preparation. Saaida effectively marshals family resources to get her son admitted to what she believes is an advantageous academic environment. She takes a similar approach to financial support of the school. At the time of the interview, Saaida had only been a PSX parent for a couple of months, but she estimated already contributing about $\$ 1800$ to the school and PTA. She purchased more than $\$ 100$ in learning materials from the teacher's amazon.com wish list, she spent $\$ 100$ on classroom snacks and supplies for a parent-led art project, contributed $\$ 50$ for class fieldtrips, and she spent about $\$ 50$ on school branded merchandise. She also donated the PTA-suggested $\$ 1500$ for teaching assistants. She had not yet contributed to the requested $\$ 500$ to the PTA general fund, but she intended to.

The use of PTA funds was sometimes also consistent with opportunity hoarding as many PTAprovided programs and resources were intended to confer an academic edge on PSX students. Parents discussed the advantages that would accrue to their children through the introduction of teaching assistants who decreased the teacher-student ratio. Parent funds provided after school test prep courses for children in grades that take the New York State regents exam, which is a determining factor in middle school placement in New York City's competitive and high stakes school environment. Most of the additional enrichment activities provided by the PTA - 
activities such as track and field, theater and music, chess and robotics may not have such an explicit academic component, but still lead students to appear "well-rounded," a characteristic that can advantage students over other academically-qualified peers (Dumais 2006).

\section{Do more, get more}

Many parents expected that their involvement in the school would yield influence, preferential treatment, and an education that rivaled those offered at private schools. For example, Nancy Fuller is a wealthy parent in her late 40s. A native New Yorker who is white and Hispanic, Nancy has two children who attend the G\&T program at PSX and another child who attends an elite private school. She and her husband, who is also from the New York area, have brought significant money to the school through direct donations and their influence in a schoolsupporting private foundation that awarded a grant to PSX. She acknowledges that their status in the school is elevated by these financial inputs, and this means they have greater access to the school principal and receive preferential treatment. According to Nancy, this is to be expected:

There is hierarchy in private schools, too. Not just in public. For people who bring in more money and whoever does more. When people say, 'Oh, you know, they do it for their own kids.' And I always say, 'Yeah, you do get extra because you are doing more. Yeah, the people at the PTA should get their ticket first, and if you want your ticket first, show up.'

However, the opportunity hoarding explanation focuses on advantaged parents, but there are shared motivations and similar opportunity-seeking behaviors across race and class. About half of PSX students qualify for free lunch and are not white and Asian. Many parents of these students also demonstrated and expressed a motivation to obtain advantages for their child, and also made financial contributions as well as commitments of time to support the PTA and the school. This poses a challenge for the claim that opportunity hoarding, instead of the fact of inequality between parents, accounts for the rise of parent money at PSX. 
For example, Kayla wants her two children to have every advantage, and she makes use of the resources at her disposal in pursuit of this goal. A custodian in a Manhattan hospital, Kayla is African American, a single parent, and life-long New Yorker in her early 30s. She and her children live in the Bronx and travel over an hour by bus and subway to get to PSX. Her neighborhood public school has a record of low achievement and a reputation for having safety problems, so Kayla first enrolled the children in a selective charter school in Harlem. Dissatisfied there, Kayla learned about PSX from a contact in the school system. She visited the school and liked it immediately: "I saw the trophies in the front, meaning the kids can get involved in a lot of stuff. I was told that they email parents for weekend activities for the kids." Kayla enrolled her children by using the address of a relative, a resident of public housing near PSX. We spoke to other low-income, minority PSX parents who engaged in similar "boundary hopping" and past research finds such manipulations of address for school admissions (Faw and Jabbar 2016).

Kayla uses a portion of her limited financial resources to support the school and the PTA: “Money, well, I don't really have too much of that (laughter)... But I can go to [discount store] and gather up some stuff for the Halloween party, you know, I do that. I don't have too much money to give and that's why I help out with the cupcakes and stuff." She gives her children money for the bake sales and book fairs. Kayla also arranges her work schedule to accommodate PTA meetings, volunteering in her children's classrooms and the PTA office, and assisting with PTA events and fundraisers: "They do a lot of fundraising here, too. Woah, that can wipe you out! In terms of the [dollar] amount and the time commitment." 
Kayla sees PSX as a place where accumulated parent resources provide additional learning experiences and where possibilities for parental involvement give her influence over her children's education: “Ever since they've been going to PSX it's been good. If I have an issue with something, or if the teacher has an issue with something my child is doing, they communicate with me very well." The evidence suggest that Kayla has increased her children's educational opportunities. Her older child, in his final year of elementary school at the time of our interview, was held back at his previous school and they were threatening to retain him again. Despite that school's great reputation, Kayla felt they discounted her opinion regarding what is best for her child. According to Kayla, PSX was a better school because the kids had more freedom and opportunities, and because Kayla was welcome at school and felt comfortable discussing her wishes and concerns with the teachers, principal, and other parents. "It's good for the kids. My kids, when they see me going on trips with them or when they are coming down to head to lunch and they see me [in the PTA office]... It keeps them calm." As this research was drawing to a close, Kayla's older child turned around his academic performance and gained a sought-after seat in a nearby middle school with a gleaming new building, an integrated, economically and racially diverse student body, and many extracurricular and enrichment programs. His middle school was a different world from the neighborhood school Kayla left behind. This point was driven home one day when Kayla called and asked if I had heard the news about a fatal school stabbing that day in the Bronx High School that shares a building with her neighborhood elementary school. "Can you imagine if my kids were there? I'd be going crazy right now!" 
In Kayla's story we see many behaviors that might be considered opportunity hoarding when attributed to white and well-off parents -choosing schools that offer extras and special programs, influencing teacher assessments of the child's academic potential, seeking to shape the children's treatment and behavior in the classroom, and working to raise funds that support an advantageous educational environment and establish one's credential as a parent whose child should be noticed. This is consistent with past research finding that minority populations, African Americans in particular, have long worked overtime in the form of taking on extended commuting times to desirable schools (Cordes and Schwartz 2018) and engaging in fundraising and school influence through PTAs (Woyshner 2009) to establish educational opportunities for their children. The opportunity hoarding explanation does not account for this cross-class, crossrace convergence in strategies for supporting children's educational opportunities.

"I'm not worried about my daughter" Parent financial contributions and involvement at school often extend beyond parents' expectations that their child will likely benefit. Take for example Nora's involvement at PSX. Nora's older child is a G\&T student at PSX and her younger child is in a selective G\&T school across town. The family is wealthy and white. As a young adult, Nora immigrated to the United States from the former Soviet bloc. Her American-born husband works in the financial sector, where Nora also worked until she became a full-time homemaker a few years ago. When Nora first visited PSX, she was shocked by the conditions. "When I went on the school tour, I wasn't really impressed. I actually remember telling my husband, 'I did not immigrate all the way here so my child can go to a school looking like this." Despite her reservations, they selected PSX. 
Nora makes substantial time and financial commitments to the school. She joined the PTA immediately. She was elected to a member-at-large slot held open for new parents, and rose to assistant treasurer when the position became available a couple of months later. The next fall she was elected treasurer, a position she held for multiple years. She and her husband donate the requested amount to the TA and PTA funds. They were among the biggest spenders at the 2016 school auction with winning bids on several items and a substantial direct donation during the "paddle raise" coming to several thousand dollars in total. Nora also reported sponsoring $\$ 150$ tickets to the auction for a couple of teachers each year, as well as making treats for the bake sales, shopping at the book fairs, and contributing to all the other fundraisers and requests for assistance from the teachers and school. In addition to the large financial commitment, Nora estimates spending 30 hours a week on her PTA responsibilities. She also volunteers one day a week as a classroom assistant, chaperones fieldtrips, and attends classroom events for parents. Nora sees time commitments like hers as typical for New York City and compares her involvement with that of her sister, who lives in another state:

They pay the PTA membership fee, which is $\$ 60$, and then they participate in a bake sale, and they participate in 'Go eat at your favorite restaurant' and the restaurant donates $10 \%$ to the school. Just little things. Why does it become a full-time job for us? And I get that this is maybe just a combination of the work culture in New York City and also the magnitude of the problems that are faced in a public school in the city versus a wellselected population in suburbia. I think just seeing the over-crowdedness in the urban schools creates the motivation.

Nora's involvement at PSX exceeds the scope that would be expected by the economic explanation and pushes the limits of what we might reasonably call opportunity hoarding. The focus of Nora's involvement at PSX is less on directly securing educational advantages for her daughter and more on improving the school as a whole and on addressing the needs of GenEd classes in particular: 
I'm not worried about my daughter. But what I am worried about is the kids in GenEd... I

think we are failing these kids... because we are not addressing the core problems which is that these kids tend to be not where they need to be academically.

In light of this concern, Nora volunteers as an aide in a GenEd classroom one day a week.

Attention to the GenEd classes extends to her work as PTA treasurer. As she sees it, it would be easy to channel PTA funds towards G\&T students, but Nora puts effort into making sure that

GenEd students have access to PTA-funded enrichment programs:

We try very hard to make grade-wide enrichment but the problem, for example, is CloudPerfect [a large technology company] comes in for robotics in the $3^{\text {rd }}$ and $4^{\text {th }}$ grade. The GenEd teachers just don't want it. They are so focused on getting their students to pass the [New York State] tests that they just don't have time. So, enrichment sometimes steers more to the G\&T kids... So we're saying to the teacher 'OK, but what do you need?... Whatever you need, here's the money.' But, no. Unless I find the program and I chase everybody around, it doesn't happen.

Thus, Nora sees her work at the school as separate from and having limited impact on her

daughter's school experience:

I've gone through periods these [few] years when I just don't want to deal with it. I know I can't change it. I just want to go in for a classroom party, see my kid, and go out... It's hard to reconcile that your child is having a fabulous time. She's reading like a champ. She loves going to school, and meanwhile I'm just miserable emailing all day and all night and talking to my board members and all that.

There is evidence of opportunity hoarding at PSX, but the opportunity hoarding explanation's assumption is that better-off parents' unique motivations and advantage seeking behaviors lead to their financial contributions and other advantage producing behaviors. This assumption is inconsistent with the cross-class convergence in parent motivations and strategies at PSX. Furthermore, the opportunity hoarding explanation does not acknowledge the social commitments and concerns for justice that can also motivate parent fundraising.

\section{Civic Engagement and Social Capital}

The civic engagement explanation sees parent involvement as an important contribution that builds the social capital of parents and strengthens the foundations of American democracy and 
civil society (Christensen et al. 2016, Crawford and Levitt 1999, Putnam 2000, Small 2010).

Consistent with this explanation, many PSX parents feel a sense of collective purpose and attachment in their support of the school. However, the civic and social capital objectives of parental involvement could also be stymied by the emphasis on fundraising, contributing to the reproduction of inequality between parents.

\section{The Village}

Many PSX parents believed that parents should do what they can to support public schools.

Kayla, the parent who commutes from the Bronx as discussed above, said that she is someone who likes to be involved, but that everyone, whether they like it or not, should contribute. Nancy Fuller, the parent who believes that involved parents should get special treatment, put it this way, "You have to support your public school and if you don't, you probably should leave."

This normative view was often tied to a sense of collectivism. Parents referred to the school as a "community" or a "family." Nancy called it "my village." Kayla feels there is a direct relationship between her participation at school and building relationships: "There's a lot of parent involvement. You know, the PTA meetings are great.” Kayla reported that she was pleased when, during the meetings, members of the executive board gave her a "shout out" for the effort she expended planning and running the Halloween party. Such moments conveyed a sense of respect, appreciation, and mutuality among the parents. According to Nancy, PTA "involvement was a way to figure out who you are going to be friends with. One of the things I really appreciate about the school is I have made friends with people that I just so admire." Other parents described sharing information with other parents and helping out with each other's children. 


\section{Greater Involvement}

The civic engagement perspective also highlights the role of parent involvement as a gateway to greater civic participation. Most PSX parents limited their involvement to the PTA and other school-based volunteering such as serving as a class parent or a classroom assistant, but PTA involvement also fostered greater civic participation. For example, a native New Yorker, and an African American woman in her mid-30s, Nicole is a single parent and college graduate with health issues that keep her from working. She and her son live in public housing and she collects welfare and child support to make ends meet. Her child is a GenEd student. Her first year at PSX, Nicole was encouraged by some of the board members to run for a spot on the EB. She was elected and served in different capacities for many years, often as the self-described "unicorn" standing out as the only GenEd parent of color and resident of public housing on the EB.

Although she believes a couple of EB members are hostile to the school's lower income families, Nicole feels comfortable with the other parents despite the racial boundary and income gap. She refers to the parents of PSX as a family, and she characterizes the school as warm, open, and nice, a small and personal environment where her son is safe and secure. Of course, she says, when he started school, "I didn't worry. I was always there." She laughs, "I'm around" by which she means that she is a fixture at PSX. After that first year on the PTA, Nicole was asked to run for a position on the School Leadership Team (SLT - an elected representative of PSX parents in dealing with curricular issues at the school level). At the time of our interview, Nicole was also on the citywide ballot for the Community Education Council (CEC - an elected representative of school district parents in the formation of education policy at the district level). She was not elected but would consider running again in the future. 
Nicole says she is too involved at school. In addition to her positions on the PTA and SLT, she is class parent for her son's class. When asked what school events she participates in, she says, “everything, but not so much the gala cause I don't have connections (laugh) so they are covered with that... If you have connections, you should be on the gala." When Nicole estimated her time commitment to the school for the month, she listed her tasks:

I go [to the PTA office] probably like two or three times a week, and then if I don't have a doctor's appointment or if there are other things going on, then more. Like if there is the bake sale, then I have to take care of that. And if people are dropping off money, I have to collect the money, and I have to email parent reminders. We have the PTA meeting at the beginning of the month. I prepare for that and help out with that. We have executive board meetings. Prepare for that and be there for that. And then, of course, if we need to backpack anything [sending home notices], I'll have to make copies and backpack them out... Sending out emails. Reminders, reminders, reminders: make sure the kids have their money, because if they don't bring their money, how are you going to sell? Then I have the SLT meeting every third Wednesday.

Nicole struggled to estimate her time commitment to the school, but noted that on a busy week she spent nearly as many hours at the school as her son.

Consistent with the social capital and civic engagement explanation, Nicole's involvement connected her to other parents and facilitated greater civic engagement in the school and potentially in the district. Although prosocial motivations and the development of networks of engaged parents do provide some support to the civic engagement and social capital explanation, there were limits to the value of this explanation for understanding parent fundraising.

Fundraisers and Friendraisers

The pursuit of funds was pervasive, acting both as a motivation for involvement and a limiting factor in opportunities for participation and community building at PSX. This is clear in Nicole's experience with the PSX gala. "I went to the gala once," Nicole said wistfully as we chatted one day. In her first year on the EB, a G\&T parent gave her a spare ticket she had purchased. Nicole 
had a great time and would love to go again, but the cost of the ticket was beyond her. Every year she hoped someone would give her another ticket, but, apart from that first year, Nicole's tireless efforts on behalf of the PTA and the school had never been rewarded with, as Nancy put it, "that little bit extra."

Nicole did not get a free ticket to the gala because the event was considered a fundraiser, not a "friendraiser." These terms were used by EB members to designate the purpose of activities. Considerations of inclusivity and equity were sidelined for fundraisers. In my early days at PSX, I met with Clara, PTA vice president. Clara explained that the board would let me observe them, but I could not attend the gala unless I purchased a \$150 ticket. There were limited tickets, she explained, and the revenue from the event was absolutely crucial to the liquidity of the PTA. It was difficult to deny people the opportunity to attend, she said, but it was necessary. Meanwhile, most of other PTA activities - including the Halloween party, the neighborhood fair, bake sales, and book fairs- were considered friendraisers with the primary purposes of fostering community even though those events often also focused primarily on raising money. In the prevalence of fundraising even as a friendraising activity, we have the answer to the earlier question of why the PTA would continue to hold bake sales when there was no need for funds. Such events made it possible for parents who could not attend the gala or write a check to the PTA to feel that they were active, contributing PSX parents. Fundraising, even when the funds are not needed, is the modus operandi for parental involvement in the school.

The emphasis on fundraising limited the democratic potential of the PTA. During the meeting in which she told me I would have to buy a ticket to the gala, Clara described the challenges of 
encouraging PTA involvement among GenEd parents. I had similar conversations with other active parents, and observed meetings in which EB members discussed this issue at length. However, during PTA elections each Spring this research was ongoing, multiple GenEd parents ran for positions on the EB, very few were elected.

One such parent, a grandparent actually, was Victoria Gonzalez. The day of the Spring 2015 election approximately 90 parents were seated in the auditorium as candidates for the EB courted their votes. In the first four rows, center, a group of about 30 parents sat closely together, chatting and facing forward. Other parents were scattered throughout the auditorium, sitting alone or in pairs.

When she was announced as a candidate for the entry level member-at-large position, Victoria Gonzalez approached the microphone, which stood on the floor between the first row of seats and the stage. She had been seated at the far side of the room. A Latinx woman in her late 60s, Victoria read a prepared statement, her eyes rarely rising from the paper:

My name is Victoria Gonzalez. I'm a mother of 3 and a grandmother of 7. I have 2 grandchildren that I have full custody of that are here at PSX. I also have two kids who are 27 and 28 and they also graduated from PSX, so that makes me a little familiar with PSX. So, this year I am running for member at large. I know that some of you may probably be wondering why it took me so long to join the PTA. One answer would be that I had no time to come to any of the meetings let alone to join the PTA. I've worked so much and I have always had two, three a few or several jobs at a time. I lived around this neighborhood for around 24-25 years. I've been involved in the community, and I am a fast learner. What I don't know I will learn. I have more time now because I am retired. The time I have I can use to be helpful to the PTA...

Next to the microphone was Victoria's competitor, Jamie Mellan, who rose from her seat in the group of parents sitting front and center and walked the two or three steps to the mic. A white 
woman in her mid or late 30s, Jamie stood tall, spoke without notes, and mostly trained her eyes on the crowd at the front of the auditorium. She said, "I'm Jamie Mellan and I know most of you down front." She smiled at the people she had just been sitting with.

I am very committed to this school, and I want it to be as good as it could be. I have a first grader in this school and next year my middle son will be in kindergarten G\&T [gifted and talented] as well. A bit about myself: I'm [in television] and I serve on the board of [important organization for people in entertainment industry]. I also run a charity that works to bring the arts to children. I've been very active in the school. I try to fundraise for Teaching Assistants and think we should have full time TAs for every class. Regardless of how things go today, I will be involved with the school. I will fundraise and I will be there for events.

Later, when I asked parents why Victoria was not elected and Jamie was despite the lack of GenEd representation on the board, I received a variety of responses such as it being safer to choose the person you knew, differences in style of addressing the audience made Jamie look more like "leadership material," and Jamie's experience with fundraising and outside connections would be an asset to the organization as it pursued its fundraising goals. When you plan to raise $\$ 450,000$ with a team of volunteers, considerations of inclusivity only carry so much weight.

In Nicole's and Victoria's exclusions we see a limitation of the civic engagement and social capital explanation. Inequality between parents was often reproduced in the construction of parent networks and the distribution of the "spoils" of participation. Parents in a position to give more money got more access to the organization and the elite events it organized. Although they may be just as dedicated to PSX, parents with less money participated differently. However, just as Nicole fantasized about another chance to attend the gala and parents like Victoria were denied access to the EB, rarely did parents complain in the face of such exclusions. When I 
asked Kayla if she had ever been encouraged to run for a position on the board. She said she had not, but she didn't mind. Since she did not know a lot about running an organization, she thought it was best to stick to volunteering. I spoke with Xenia, a GenEd parent who was African American and who was elected to the EB when a space opened unexpectedly in Fall 2017, but was not reelected to the position the following year. When I asked her why she was not reelected, she shrugged, “They have already told us our money isn't good enough, so why should I be surprised if my work for the PTA wasn't good enough?”

\section{The Normative and Institutional Context}

At PSX there is a convergence on fundraising that is not accounted for by the economic, opportunity hoarding, and civic engagement explanations. This convergence suggests a shared normative and institutional context making fundraising the natural response to the lack of public money, an accepted element of parental support of children's education and opportunity, and a crucial element of how one builds parent community. Making sense of this convergence is a key to understanding the rise of parent money in public schools. In this section I consider the rise of this normative and institutional context at the national, city, and school levels and link it to the beliefs and practices that shape parents into school funders.

Parents Need to Be Involved

Concurrent with rising parent financial contributions to public schools in the mid-1990s, national educational policy emphasized parental involvement as a key component of school quality. On March 31, 1994, President Bill Clinton stood before an assembled crowd of students, teachers, school administrators, and politicians in San Diego California for the signing of his educational bill, Goals 2000: Educate America Act (H.R. 1804). The legislation supported the creation of national standards for schools and for student achievement and laid out the assessment criteria 
for establishing that the standards were met (Schwartz et al. 2010, Superfine 2005). ${ }^{10}$ As he described Goals 2000, Clinton pointed out that parents and communities were also the focus of the new policy. "We can't succeed in our schools unless parents are more involved, and we have to find ways to help them do it”, he said (William J. Clinton Presidential Library 1994). This emphasis on parental involvement, which had begun in educational policy circles in the 1980s, was now the law of the land. ${ }^{11}$ Prompted by Goals 2000, many states and municipalities increased their outreach to families. Responding to Goals 2000, New York State required that all New York City schools have an active parent association or parent-teacher association, a school leadership team such as the one Nicole served on at PSX, and a community education council, such as the one to which Nicole hoped to be elected. ${ }^{12}$

In 2002 Michael Bloomberg, the newly elected mayor of New York City, implemented educational reforms. His predecessor, Giuliani, had resisted Clinton's federal guidelines (Newfield 2002). Goals 2000 was now a thing of the past, replaced in early 2002 by Bush's No Child Left Behind, but the focus on parental involvement was retained in the new national legislation. Children First, as Bloomberg's reforms were called, emphasized improving

\footnotetext{
10 The bill, legislative history, and descriptive text are available here: https://www.govtrack.us/congress/bills/103/hr1804

11 Goals 2000's emphasis on parents would not have been possible without the work of Joyce L. Epstein, the education researcher who brought the idea of parental involvement into the policy mainstream (see Epstein 1991 for an example of Epstein's leadership on parental involvement). Epstein argues that schools, families, and communities are "spheres of influence" that ought to be connected through school, family, and community partnerships. Correspondingly, schools should develop programs geared toward establishing six types of involvement: parenting, communicating, volunteering, learning at home, decision-making, and community collaboration. This perspective on the desirability of parental involvement was also consistent with popular scholarly thinking that the rise of mother's labor force participation led to a corresponding decline in social capital in schools and their surrounding communities (Coleman 1987).

12 see state law The Laws Of New York Consolidated Laws Education Title 2: School District Organization Article $52-$ A: New York City Community School District System, Section 2590-C.
} 
communication between schools, parents, and communities (O’Day and Bitter 2011, Henig et al. 2011). Each school received a full-time parent coordinator - a paid administrative staff member responsible for managing school-parent relationships and coordinating with PTAs and other community organizations that work with and serve the city's public schools (Gootman 2003, Henig et al. 2011). Schools were directed to expand their collaboration with educationsupporting organizations (Henig et al. 2011). Solicitation of parent input was formalized through the development of an annual survey of all parents. Along with students' performance on exams, an annual quality review carried out by a department assessor, and an annual survey of teachers, the parent responses to these surveys were incorporated in a performance assessment of schools.

\section{Pursuing PSX Parents}

With the reforms, New York City schools were now evaluated partly on the basis of their relationship with parents. The data comes from a parent survey, and parent responses are used to grade the school's leadership, family and community ties, and level of trust. Schools were also evaluated by assessors who considered the school's success in forming community partnerships. Principals therefore had an interest in engaging parents and keeping them happy, and a need to collect evidence of their relationships with parents.

Relationships with parents were a concern for PSX's Principal Sue. She was new to PSX and a new principal. The transition was not a smooth one, and Sue and the PTA had a contentious relationship for most of the time this research was ongoing. For example, in Spring 2018 the parents unsuccessfully lobbied the district to have Sue removed. Meanwhile, the beleaguered principal solicited PTA support for staff development. Despite the availability of funds, the PTA declined her request. Yet, when I asked Sue if it would be easier if parents were not so important 
to the funding or educational mission of the school, Sue disagreed. She said that is important for parents to be involved. They are needed, she said, their financial support and volunteering were essential, even if inconvenient and troublesome at times.

From the perspective of the principal, reaching out to the parents wasn't optional, it was necessary - not just because parents provided money and labor to an under-resourced institution, but because the district demanded parental engagement. Independently of the PTA the PSX administration implemented measures to engage parents. Monthly events included "learn with your child" and "math mornings" in which parents were instructed in an educational technique used in the classroom. There was a monthly coffee hour with the principal. A few times a year the school offered workshops in which experts came to discuss parenting challenges. The school invited parent volunteers to participate in a training program and, upon completion, work shifts supervising lunch and recess. Teachers contacted parents when they needed supplies. Parents were also encouraged to volunteer in the classroom, to assist teachers by chaperoning fieldtrips, and to fund and plan the graduation ceremony for the $5^{\text {th }}$ grade class. These observations at PSX are consistent with the research finding that teachers and school administrators expect parental involvement and attempt to shape that involvement to their own liking (Lareau and Munoz 2012).

\section{Recognizing Good Parents in a Good School}

The idea that involved parents were important to the school was generally held by PSX parents, too. In describing how they selected the school, many parents discussed attending an information night for prospective families. At those events EB members highlighted the PTA budget and PTA-funded enrichment activities. In interviews, some parents discussed comparing the PSX 
PTA budget with PTA budgets of other elementary schools. A couple of parents admitted that PSX had been their second choice to the G\&T program at nearby PS Y, a school known throughout the district for its, as one parent put it, "million-dollar PTA."

Given the connection between parent-involvement and assessments of school quality, even parents who did not believe their financial support or volunteering was would impact their children's education directly had an incentive to be engaged in order to ensure that the school retained its reputation. A PTA budget, a list of parent-provided enrichment activities, and the smaller child-to-teacher ratios resulting from parent-funded teaching assistants provided easy to read metrics of just how involved PSX parents were, reflecting favorably on the school. As a result, each year the PTA expanded their offerings and requested even larger financial contributions from parents. Over the course of this research, the requested contribution was increased substantially, from just a few hundred dollars per child to $\$ 2000$. Fundraising totals increased by more than $30 \%$ over the period of data collection. The PTA sought other indicators of involvement. For example, during fundraising for the playground, Nora reminded parents that it would be an advantage to the school if they could claim there was $100 \%$ participation in the coin-drive.

Parental involvement is not only a factor in the evaluation of the school, it is also a consideration in the evaluation of the parents. Past research confirms that school staff may evaluate parents on the basis of their involvement, and report treating students with involved parents differently (Calarco 2018; Lareau and Munoz 2012; Lewis and Diamond 2018; Posey-Maddox 2014). Parents evaluated one another on the basis of participation as well. That point was driven home 
when I volunteered at the Valentine's day bake sale. Hannah, a white European-immigrant parent with two students in G\&T classes and a preschool child at her side, worked with me. I asked if she was very involved in the PTA, and Hannah replied, "Not very. But I do go to all the meetings and help out at the bake sales and things. I guess you could say that I am involved because a lot of people don't do anything. You probably see a lot of the same parents at these things." I agreed. Hannah nodded, and continued with a scornful tone, "Well, I think it comes to the decision if you want to just let the State raise your children. In that case, you don't need to do anything." Hannah distinguished between engaged parents and those, it was clear from her tone, she thought of as lazy and inadequate. Likewise Jen, a pre-K parent who is Asian American and works in the financial sector, was struggling with other parents in her daughter's class. Pre-K is the only year when there is not G\&T and GenEd segregation at PSX and the income gap loomed large in Jen's experience:

Probably $50 \%$ of the kids in my daughter's class can't pay the cost of admissions for field trips. The teacher has to put up the money. I feel so bad about that.

However, while Jen understands that background inequalities shape the experiences of parents,

she also interprets involvement as distinguishing parents are caring from those who are uncaring:

Only 5 of us are the ones who are always pitching in. I don't know if it's that we are the only ones who are financially able to.... Once I got so mad over Thanksgiving and we had to do handprints of each child and then write happy holidays to the teacher... I approached the parents and asked if I could do their child's handprint for the teacher. One of the parents said, “No. I don't care. Who cares?" I was like, Wow. These teachers put in so much for your child, and you can't even give me a handprint to say thank you. For some of the parents there is no gratitude... I don't want to say that they don't care as much...

Charting the policy context leading to increased emphasis on parental participation and connecting that to explicit criteria of evaluation of schools and implicit criteria of evaluation for parents demonstrates that the convergence on parent fundraising is connected to a particular normative and institutional context. Rising parental support for schools coincides with increased 
demands for parental involvement, which were formalized in national educational policy in the 1990s and implemented in New York City. As established by policy, a good school is a school with engaged parents, prompting PSX's interest in fostering parental involvement and parents' attentions to parental involvement. Given the emphasis on involvement, PTA fundraising totals and the menu of programs funded by the parents provide easy to read metrics about parental engagement in the school, which are taken as a measure of school and parent quality.

\section{Discussion}

The rise of PTAs and PTA fundraising demonstrates significant cross-contextual coordination that is difficult to explain through parents' opportunism alone. Instead, the rise of parent money in public schools depends more on the normative and institutional contexts of parenting and schooling than on any extraordinary needs, interests, or civic aspirations on the part of parents. The outcome of this logic of parent money is in full effect at the PSX Gala.

\section{What's another \$1000?}

The 2016 Public School X Annual Gala and Auction was held on a cloudy and chilly early Spring evening. The lights were dim and a low-level electronic soundtrack pulsed in the erstwhile factory turned event space donated by the owner - a friend of the school. Two bars offered specialty drinks and two food stations distributed a number of Caribbean-themed small plates. Cocktail tables were scattered about the room.

The PTA asked parents to solicit donations for the gala. The resulting silent auction merchandise -from jewelry, to hotel rooms in major cities and resort towns around the country, to tickets to the latest Broadway shows and athletic events, to art produced by parents and friends of the 
school - were displayed and described on $8.5 \times 11$ pieces of paper laid out on many long tables. The premium items for the evenings' live auction were listed as well - passes to a filming of a popular late-night talk show, tickets to sold out Broadway shows, the opportunity to meet the players of professional sports teams, and other events and experiences including the opportunity for a child to be "Principal for a day."

About 300 people were assembled when the program began. The demographics of auction attendees were quite different from the school population. There were about even amounts of white and Asian attendees, but there were very few attendees that appeared to be African American or Latinx. Principal Sue, the former principal, many of the teachers, and members of the PSX staff attended as guests of the PTA. The PTA president thanked everyone for coming. Then the lights dimmed for the screening of school's capital campaign video. Created by a professional film producer with ties to the school, the short video focused on a student named Natasha. She was an African American GenEd student who loves the PSX music program. Interspersed with descriptions of the music program, interviews with teachers, and clips in which Natasha talked about her experience in the program, we saw footage of music and dance classes. With sappy pop music layered under the audio to maximize the emotional impact, Natasha explained that music and dance made sense to her when things in the class did not, that they provided the opportunity to be creative and free. In a clip, the vice president of the PTA pointed out that the music program makes it possible to reach students who might be lost without the arts to supplement academics. There was a crescendo of music and images of happy kids doing music together. Things grew quiet as the screen went dark and the words "Please Give" appeared. 
The gala attendees applauded, some wiping away tears, as a professional auctioneer who had volunteered for the event took command of the room. In general, bidding was dominated by a handful of people. Only about 50 attendees ever raised their paddles. There were only about 15 "heavy hitters" who were willing to bid on the most expensive items. One parent who stood watching said that she was interested in bidding on the two Hamilton tickets but that she supposed they, like everything else, would end up being too expensive. She would only go as high as $\$ 1000$, she said. As she predicted, the high bid for the tickets was $\$ 4500$. At one point, one of the teachers responded with mild annoyance to no one in particular as the auctioneer cajoled a parent to increase their bid on a private dinner cooked in your home by a well-known NYC chef. "What is another \$1000?" the auctioneer asked, suggesting it was a small amount. "I'm a teacher, so a lot," a teacher replied ruefully in a voice that only carried to those in close proximity. Once all the items were auctioned off, there was a "paddle raise" in which parents, in the company of the principal and other school staff, competitively outbid one another in their desire to support the school. The winner was a $\$ 4000$ bid.

Parent money in public schools has a symbolic value for schools and parents. It is a value that extends beyond the money raised. There is widespread emphasis on parental involvement and the broadly shared assumption that involved parents make for successful schools. Demanding teachers and principals, involved parents, PTAs are doing what they think they are supposed to be doing - fulfilling what they are told is a critical role in the school. The gala was a bizarre event blending and presenting the multiple logics and meanings attached to parent money. The public nature of the auction, conducted in full view of the school staff, was part opportunityhoarding potlatch in which the wealthiest parents gained status and influence through their 
bidding. It was part civic-engagement focused charity fundraiser as evidenced by the campaign video presenting a struggling African American student being saved by the arts program instead of depicting a G\&T student and the more academic enrichment offerings that G\&T families tended to prefer. The economic logic was prevalent because the targeted program in the video, the school music program, was the program the principal threatened to cut if the parents did not replace the lost public funds. All of these motivations, and the gala and auction themselves, were not unique to PSX. Tickets to the PS X Gala were sold through a third-party for-profit organization in the business of helping PTAs and other not-for-profits run auction fundraisers. Similar auctions being held throughout the country are listed on the websites of such organizations. ${ }^{13}$ Parents around the country come together to bring money into their children's schools.

\section{Conclusion}

Increased parent money in public schools coincides with the rise of the idea that parental involvement at school is crucial to the success of students. This idea was incorporated into national education policy in 1994 and subsequently disseminated to states and municipalities. In New York State, education law determined that all New York City schools must incorporate parent representation in the school through a parent-teacher organization or parent association and elected parent representatives on the school leadership team, parents would be incorporated into school governance at the district level through elected positions in community educational councils. Meanwhile, New York City educational policy created an office for parental

${ }^{13}$ See for example https://www.biddingforgood.com/auction/browse/current.action and https://www.biddingowl.com/auctions.cfm 
engagement and provided each school with a full-time parent coordinator to improve the connection between parents and schools. The city conveyed expectations that school principals should form partnerships with parents and seek the resources of parents and community organizations. This emphasis on parental engagement was evident in the regular calls for parental involvement sent out by the school. The city also developed an annual school assessment that included grading schools on their success in establishing positive relationships with parents. This assessment motivated the PSX school administration to have evidence of collaboration with parents and the broader community. An annual survey of parent satisfaction with the school provided some of the data for that assessment, proving a challenge for the unpopular new PSX principal who knew that a positive relationship with parents would improve the school assessment. It is no wonder then, that PSX developed opportunities for parental involvement and, when confronted with a loss of public financing, turned to the parents to raise the required funds. PSX parents themselves understood that their participation was crucial to the reputation and success of the school. Given the underlying normative assumptions that civic engagement is prosocial behavior, and that good parents should care about the quality of their children's school, it is no wonder then, that most PSX parents participated at school, that some parents felt ashamed or improvised when they could not meet the expectations placed on them, and that parents used involvement as a way to judge each other and introduce involvement inequality into the parent community.

Previous explanations of increased parent money in public schools take a partial view of PTA involvement and fundraising in school by leaving parents themselves at the center of the analysis. Are parents responding creatively to gaps in funding on account of the retreat of public 
support for public schools? Are they working the system to secure advantaged for their children? Or are they performing a valuable service to society? The answer is yes, they may be doing all of these things, but they are engaged in behaviors which make sense in light of the institutional demands on schools and normative expectations of parents. PTA involvement and parent fundraising are problematic but logical responses to this institutional and normative context.

That an institutional prerogative for involvement and a normative expectation of parenting around schooling fuel the rise of parent money in public schools is a plausible explanation that contributes insight lacking in economic, opportunity hoarding, and civic engagement explanations. This conclusion suggests new ways to intervene in order to mitigate the inequality that can arise from parent's involvement in their children's school. The most obvious is to revisit expectations of and demands for parental involvement and rethink the role that parental involvement plays in school assessments. In addition, including parents' volunteer hours and money in school's fiscal reporting of per student expenditures would make the public aware of this source of inequality. However, this posthoc approach would do little to eliminate the pressures and collateral impacts arising from the ascendency of the idea that parent involvement in fundraising makes for good schools and good parents. 
Bibliography

Addonizio, Michael F. 2000. "Private Funds for Public Schools." The Clearing House: A Journal of Educational Strategies, Issues and Ideas 74 (2): 70-74. doi:10.1080/00098655.2000.11478646.

Brown, Catherine, Scott Sargrad, and Meg Benner. 2017. Hidden Money: The Outsized Role of Parent Contributions in School Washington, DC: Center for American Progress. https://www.americanprogress.org/issues/education-k12/reports/2017/04/08/428484/hidden-money/ last accessed July 29, 2019.

Brunner, Eric J. and Jennifer Imazeki. 2004. "Fiscal Stress and Voluntary Contributions to Public Schools." Developments in School Finance: 39-54.

Brunner, Eric and Jon Sonstelie. 2003. "School Finance Reform and Voluntary Fiscal Federalism." Journal of Public Economics 87 (9): 2157-2185. doi:10.1016/S00472727(02)00040-3.

Calarco, Jessica McCrory. 2018. Negotiating Opportunities: How the Middle Class Secures Advantages in School. New York: Oxford University Press.

Christensen, Robert K., Richard M. Clerkin, Rebecca A. Nesbit, and Laurie E. Paarlberg. 2015. "Are Parent-Teacher Groups Leading? an Exploratory Study of Nonprofit-Government Interactions in the Public School Context." The Journal of Nonprofit Education and Leadership 6 (1).

Coleman, James S. 1987. "Families and schools." Educational researcher 16, no. 6 (1987): 3238.

Cordes, Sarah and Amy Schwartz. 2019. "Does Pupil Transportation Close the School Quality Gap? Evidence from New York City.” Research Report. Urban Institute http://files.eric.ed.gov/fulltext/ED592633.pdf last accessed July 29, 2019

Crawford, Susan and Peggy Levitt. 1999. "Social Change and Civic Engagement: The Case of the PTA." In Civic Engagement in American Democracy, edited by Theda Skocpol and Morris P. Fiorina, 249-296: Brookings Institution Press: Washington, DC, USA.

De Leon, Erwin, Katie L. Roeger, Carol J. De Vita, and Elizabeth T. Boris. 2010. "Who Helps Public Schools? Public Education Support Organizations in 2010." Urban Institute https://www.urban.org/research/publication/who-helps-public-schools-public-educationsupport-organizations-2010 last accessed June 29, 2019.

Deterding, Nancy, and Mary Waters. 2018. "Flexible Coding of In-depth Interviews: A Twentyfirst-century Approach." Sociological Methods \& Research. https://doi.org/10.1177/0049124118799377 
Devault, Marjorie L. 2006. "Introduction: What is Institutional Ethnography?" Social Problems 53 (3): 294-298.

Dixon, Mark. 2012. "Public Education Finances: 2010." US Census Bureau. https://www2.census.gov/govs/school/10f33pub.pdf last accessed June 29, 2019.

Dumais, Susan A. 2006. Early childhood cultural capital, parental habitus, and teachers' perceptions. Poetics, 34(2), 83-107.

Duneier, Mitchell. 2001. Sidewalk. New York: Farrar, Straus and Giroux.

Epstein, Joyce L. 1991. "Paths to Partnership: What we can Learn from Federal, State, District, and School Initiatives." The Phi Delta Kappan 72 (5): 344-349.

Erickson, Ken, and Donald Stull. 1997. Doing team ethnography: Warnings and advice. Thousand Oaks, CA: Sage Publications.

Faw, Leah, and Huriya Jabbar. 2016. "Poor Choices: The Sociopolitical Context of 'Grand Theft Education." Urban Education. https://doi.org/10.1177/0042085916651322

Gootman, Elissa, and Robert Gebeloff. 2008. "Fewer Children Entering Gifted Programs." The New York Times. http://Nytimes.Com/2008/10/30/Nyregion/30gifted.Html.

Griffith, Alison I. and Dorothy E. Smith. 2005. Mothering for Schooling. New York: RoutledgeFalmer.

Haar, Charlene K. 2002. The Politics of the PTA. New Brunswick N.J.: Transaction Publishers.

Hanselman, Paul, and Jeremy E. Fiel. 2017. "School opportunity hoarding? Racial segregation and access to high growth schools." Social Forces 95(3): 1077-1104.

Henig, Jeffrey R., Marion Orr, and Megan Silander. 2010. "Parent and Community Engagement in NYC and the Sustainability Challenge for Urban Education Reform." Prepared for the New York City Education Reform Retrospective Project. https://www.edweek.org/media/12nyc_chapter_2_public_engagement.pdf last accessed July 29, 2019.

Lareau, Annette. Home advantage: Social class and parental intervention in elementary education. Rowman \& Littlefield Publishers, 2000.

Lareau, Annette and Vanessa Lopes Muñoz. 2012. "“You're Not Going to Call the Shots" Structural Conflicts between the Principal and the PTO at a Suburban Public Elementary School." Sociology of Education 85 (3): 201-218.

Lewis, Amanda E., and John B. Diamond. Despite the best intentions: How racial inequality thrives in good schools. Oxford University Press, 2015.

Marcus, George E. 1995. "Ethnography in/of the World System: The Emergence of Multi-Sited Ethnography." Annual Review of Anthropology 24 (1): 95-117. 
Murray, Brittany, Thurston Domina, Linda Renzulli, and Rebecca Boylan. 2019. 'Civil society goes to school: Parent teacher associations and the equality of educational opportunity." RSF: Russell Sage Foundation Journal of the Social Sciences 5(3), 41-63.

Nelson, Ashlyn Aiko and Beth Gazley. 2014. "The Rise of School-Supporting Nonprofits." Education Finance and Policy 9 (4): 1-26. doi:10.1162/EDFP_a_00146.

Newfield, Jack. 2002. The Full Rudy: The Man, the Mayor, the Myth Thunder's Mouth Press/Nation Books.

O'Day, Jennifer A., Catherine S. Bitter, and Louis M. Gomez. 2011. Education Reform in New York City: Ambitious Change in the Nation's most Complex School System. ERIC.

Posey-Maddox, Linn. 2014. When Middle-Class Parents Choose Urban Schools: Class, Race, and the Challenge of Equity in Public Education. Chicago: The University of Chicago Press.

Putnam, Robert D. 2000. Bowling Alone: The Collapse and Revival of American Community. New York: Simon \& Schuster.

Rankin, Janet. 2017. Conducting analysis in institutional ethnography: Guidance and cautions. International Journal of Qualitative Methods, 16(1), 1609406917734472.

Reed, Isaac. 2011. Interpretation and social knowledge : on the use of theory in the human sciences. Chicago: The University of Chicago Press.

Reeves, Richard V. 2017. Dream Hoarders: How the American Upper Middle Class is Leaving Everyone Else in the Dust, Why that is a Problem, and what to do about It Brookings Institution Press.

Sattin-Bajaj, Carolyn, and Allison Roda. 2018. "Opportunity hoarding in school choice contexts: The role of policy design in promoting middle-class parents' exclusionary behaviors." Educational Policy, 0895904818802106.

Schwartz, Robert B., Marian A. Robinson, Michael W. Kirst, and David L. Kirp. 2000. "Goals 2000 and the Standards Movement." Brookings Papers on Education Policy (3): 173-214.

Verba, Sidney, Kay Lehman Schlozman, and Henry E. Brady. Voice and equality: Civic voluntarism in American politics. Cambridge: Harvard University Press, 1995.

Skocpol, Theda. 2013. Diminished democracy: From membership to management in American civic life. Tulsa: University of Oklahoma Press.

Small, Mario Luis. 2009. Unanticipated Gains: Origins of Network Inequality in Everyday Life. New York: Oxford University Press.

Smith, Dorothy E. 2005. Institutional Ethnography: A Sociology for People. Walnut Creek, CA: AltaMira Press. 
Superfine, Benjamin Michael. 2005. "The Politics of Accountability: The Rise and Fall of Goals 2000." American Journal of Education 112 (1): 10-43.

Tilly, Charles. 1998. Durable Inequality Univ of California Press.

United States Census Bureau. 2017. ’2013-2017 American Community Survey 5-Year Estimates." https://factfinder.census.gov

William J. Clinton Presidential Library. 1994. "Master Tape \#s01954-01956 Remarks on Signing the Goals 2000: Educate America Act in San Diego March 31, 1994." https://www.youtube.com/watch?v=-0QsiFzJUzQ, last accessed June 29, 2019.

Woyshner, Christine. 2009. The National PTA, Race, and Civic Engagement, 1897-1970. Columbus, OH: The Ohio State University Press. 


\begin{tabular}{|c|c|}
\hline \multicolumn{2}{|c|}{ TABLE 1. PTA-Funded Enrichment by Grad } \\
\hline Grade & Programs \\
\hline \multirow{2}{*}{ Pre-kindergarten } & Creative Dance \\
\hline & Music \\
\hline \multirow[t]{4}{*}{ Kindergarten } & Chess \\
\hline & Fine Arts \\
\hline & Music \\
\hline & Healthy Eating Program \\
\hline \multirow{4}{*}{ Grade 1} & Music \\
\hline & Chess \\
\hline & Healthy Eating Program \\
\hline & Gardening Program \\
\hline \multirow{7}{*}{ Grade 2} & Music \\
\hline & Chess \\
\hline & Park Partnership \\
\hline & Architecture Program \\
\hline & Birdwatching \\
\hline & Modern Art Program \\
\hline & Theater Program \\
\hline \multirow[t]{6}{*}{ Grade 3} & Music \\
\hline & Chess \\
\hline & Robotics \\
\hline & Theater Program \\
\hline & Track \& Field \\
\hline & Test Prep \\
\hline \multirow[t]{4}{*}{ Grade 4} & Robotics \\
\hline & Music \\
\hline & Track \& Field \\
\hline & Test Prep \\
\hline \multirow[t]{5}{*}{ Grade 5} & Ballroom Dancing \\
\hline & Music \\
\hline & History Program \\
\hline & Track \& Field \\
\hline & Test Prep \\
\hline
\end{tabular}

